\title{
Comparison of time-resolved fluoroimmunoassay for clenbuterol residues in pig liver with enzyme-linked immunosorbent assay
}

\author{
L.Bi. Wang ${ }^{1}$, X.Q. Li ${ }^{2}$, Ti M. Huo ${ }^{2}$, Ke $\mathrm{Li}^{2}$ and Ch.-L. Xu' \\ ${ }^{1}$ TianJin Academy of Inspection and Quarantine \\ 300457 TianJin, P.R. China \\ ${ }^{2}$ School of Food Science and Technology, Southern Yangtze University \\ 1800 Lihu Road, Wuxi, Jiangsu Province, 214122 P.R. China
}

(Received 23 November 2006; revised version 1 August 2007; accepted 21 November 2007)

\begin{abstract}
A time-resolved fluoroimmunoassay (TR-FIA) for determination of clenbuterol (CLB) in pig liver was developed. The limit of detection (LOD) was $0.02 \mathrm{ng} \mathrm{g}^{-1}$ and limit of quantification (LOQ), $0.08 \mathrm{ng} \mathrm{g}^{-1}$. Recoveries ranged from 89.3 to $117.9 \%$ for pig liver at spiked levels of $0.1-5 \mathrm{ng} \mathrm{g}^{-1}$. The results obtained by the TR-FIA and enzyme-linked immunosorbent assay (ELISA) showed a good correlation. The established TR-FIA was applied for screening pig liver from the local market and confirmed by gas chromatography-mass spectrometry (GC-MS). This proposed technique could be used for routine screening for drug residues.
\end{abstract}

KEY WORDS: time-resolved fluoroimmunoassay, clenbuterol, ELISA, liver, pig

\section{INTRODUCTION}

Clenbuterol (4-amino- $\alpha$-[(tert-butylamino)methyl]-3,5-dichlorobenzyl alcohol hydrochloride, CLB), a sympathomimetic drug with potent $\beta$-adrenoceptor stimulating properties, can effectively prevent and reverse bronchoconstriction and has been used for the treatment of the pulmonary diseases in veterinary and clinical medicine. Some studies have reported that $\beta_{2}$-agonists, including clenbuterol, can promote muscle growth and reduce body fat (Hooijerink et al., 1991). Recently,

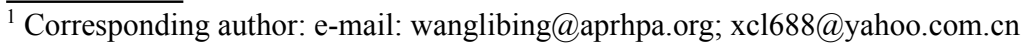


the misuse of $\beta_{2}$-agonists in animal feeds and the residues of these compounds in animal tissue have drawn substantial attention. When animals are treated with a $\beta_{2}$-agonist, residues can accumulate in their muscles and liver, and may have a pharmacological effect in humans (Navarro-Martinez, 1990; Salleras et al., 1995). Therefore, the use of $\beta_{2}$-agonists in meat-producing animals is now banned.

Consequently, the development of highly specific, reliable and low-cost methods for rapid determination of clenbuterol in diverse matrices is urgently needed. Various analytical methods have been reported for detecting clenbuterol in animal tissues or urine (Polettini, 1996; Mitchell and Dunnavan, 1998). The method currently used by most laboratories is gas chromatography-mass spectrometry (GC-MS) (Ramos et al., 2003) and high performance liquid chromatography (HPLC). Ultraviolet (UV) detection is the most popular detection method applied in HPLC, but it is limited due to low sensitivity (Song et al., 2003). HPLC-MSMS is a powerful analytical method for the detection of clenbuterol, however, the complicated and expensive instrument does not belong to the facilities of the average investigator (Van Hoof et al., 2005).

In China, inspection of animal tissues plays an important role, but it has not brought satisfactory results due to the low levels of substances in tissues and complex matrices. Recently, some studies in China were carried out on $\beta_{2}$-agonist residues in domestic animal food. Some surprising results were obtained, for example, some meat samples have above $0.1 \mathrm{mg} \mathrm{kg}^{-1}$ clenbuterol (CLB) residues. CLB residues are always found in pig livers in China. Developing more sensitive methods for screening animal food products for $\beta_{2}$-agonist residues in China is worthwhile.

While residue levels can be detected by instrumental analysis, the large number of samples and labour- and time-intensive analysis required for thorough monitoring led us to develop an alternative method, suitable for trace element testing by technically competent personnel. Immunoassay is the most suitable testing method for rapid field analysis of agrochemical residues (Dykman and Bogatyrev, 1997).

Enzyme-linked immunosorbent assays (ELISA) for laboratory analysis of clenbuterol in microwells have been developed. These laboratory assays were applied to the quantitation of clenbuterol in animal tissues. Enzyme immunoassay (EIA) methods have their disadvantages. The operation is quick and simple, but the limit of detection of the present colorimetric ELISA is about $0.1 \mathrm{ng} \mathrm{g}^{-1}$ (Xu et al., 2005).

Time-resolved fluoroimmunoassays (TR-FIAs) have been utilized in the analysis of veterinary drugs (Elliott et al., 1994; Tuomola et al., 2002). In this paper, we developed and validated a novel, rapid, more sensitive, trace method for CLB residue screening of pig liver tissues by using TR-FIA and compared it with ELISAs. 


\section{MATERIAL AND METHODS}

\section{Reagents and apparatus}

Clenbuterol hydrochloride (CLB), ovalbumin (OVA), and bovine serum albumin (BSA) were obtained from Sigma (St. Louis, MO, USA) and goat anti-rabbit IgG, acetonitrile and methanol from Boao Biotech Co., Ltd. (Shanghai, China). Dry N, N-dimethylformamide was obtained from Fluka (Buchs, Switzerland), Germall II and intrinsically fluorescent europium chelate $\left[2,2^{\prime}, 2^{\prime \prime}, 2^{\prime \prime}(\{4-[(4-\right.$ isothiocyanatophenyl) ethynyl] pyridine-2,6-diyl $\}$ bis- (methylenenitrilo)) tetrakis (acetato)]-europium(III) from the Chinese Academy of Inspection and Quarantine (Beijing, China). DELFIA Assay Buffer, Wash Solution, which is intended for in vitro use with the DELFIA ${ }^{\circledR}$ Platewash or the AutoDELFIA Automatic Immunoassay System after dilution with distilled water, Enhancement Solution, and Victor 1420 Multilabel Counter were obtained from PerkinElmer Life and Analytical Sciences (Shanghai, China). Non-coated, yellow (UV-quenched, lowfluorescence) MaxiSorp microtitration wells were purchased from Nunc A/S (Roskilde, Denmark). N,O-bis(trimethylsilyl) trifluoroacetamide (BSTFA), 0.1 $\mathrm{ml}$ ampules (lot: LB 10799), was obtained from Supelco Inc.(Oakville,ON,USA). Other reagents were of analytical quality and were supplied by Shanghai Reagent Corporation (Shanghai, China).

\section{Preparation of immunosensitive microtitration wells}

The microtitration wells were coated with activated anti-rabbit IgG $(120 \mu \mathrm{l}$ per well) and incubated overnight at room temperature in a humid environment. The wells were washed twice with DELFIA Wash Solution and then saturated with 50 $\mathrm{mM} \mathrm{NaH} \mathrm{PO}_{4}, \mathrm{pH} 4.5$, containing, 6 sorbitol, 0.1 BSA and $0.05 \%$ Germall II (250 $\mu \mathrm{l}$ per well). After overnight incubation at room temperature in a humid environment, the wells were aspirated to dryness and stored in sealed packages with desiccant at $4^{\circ} \mathrm{C}$.

\section{Preparation of labelled analyte}

The CLB-BSA conjugate was labelled overnight at room temperature with a 50fold molar excess of europium chelate in a volume of $1 \mathrm{ml}$ in $50 \mathrm{mM}$ carbonate buffer $\left(\mathrm{pH} 8.5,50 \mathrm{mM} \mathrm{Na}_{2} \mathrm{CO}_{3}-\mathrm{NaHCO}_{3}, 0.155 \mathrm{M} \mathrm{NaCl}\right)$. The conjugate was purified by gel filtration on a Sepharose CL-6B column (Boao Biotech Co., Ltd., Shanghai, China) with $50 \mathrm{mM}$ Tris- $\mathrm{HCl}$, pH 7.8, containing $0.9 \% \mathrm{NaCl}, 0.05 \% \mathrm{NaN}_{3}$. Fractions of 1.0 $\mathrm{ml}$ were collected. The fractions from the first peak with the highest labelled analyte counts were pooled to form the label stock and characterized. 


\section{Sample pretreatment}

The stock solution of CLB $\left(1 \mathrm{mg} \mathrm{ml}^{-1}\right)$ was prepared in methanol. The stock solution was stable for at least 3 months when stored at $4^{\circ} \mathrm{C}$. The working solutions were prepared daily in deionised water.

Pig liver was collected from the lab farm of our university and known to have been reared under CLB-free conditions. These tissues were stored at $-40^{\circ} \mathrm{C}$ until required. Into a glass universal $(25 \mathrm{ml})$ finely chopped tissues $(2.5 \mathrm{~g})$ were weighed and acetonitrile $(7.5 \mathrm{ml})$ added, and spiked with appropriate concentrations of CLB when necessary. The samples were homogenized for $30 \mathrm{~s}$ and $1 \mathrm{M} \mathrm{HCl}(2.5 \mathrm{ml})$ added. Petroleum ether $(5 \mathrm{ml})$ was added and the samples mixed for $15 \mathrm{~min}$ using a mixer, followed by centrifugation at $3450 \mathrm{~g}$ for $10 \mathrm{~min}$. The ether layer was discarded and the liquid phase was decanted into a glass test-tube and reduced to approximately $5 \mathrm{ml}$ under a gentle stream of nitrogen on a Driblock and sample concentrator at $100^{\circ} \mathrm{C}$. The reduction took approximately $20 \mathrm{~min}$. The supernatant was transferred to a clean test-tube and $\mathrm{NaOH}(5 \mathrm{M}, 3 \mathrm{ml})$ added. Dichloromethane $(10 \mathrm{ml})$ was added and the samples mixed using an end-over-end mixer for $15 \mathrm{~min}$, followed by centrifugation at $3450 \mathrm{~g}$ for $10 \mathrm{~min}$. The extracts were passed through phase separation columns $(6 \mathrm{ml})$ and the dichloromethane layer was collected in clean test tubes. The dichloromethane layer was evaporated to dryness (approx. 10 min) under nitrogen, using a Driblock and sample concentrator at $80^{\circ} \mathrm{C}$, resuspended in ethanol $(250 \mu \mathrm{l})$ and vortexed for $15 \mathrm{~s}$. Finally, DLEFIA dilution buffer (2250 $\mu$ l) was added.

\section{Time-resolved fluoroimmunoassay for CLB}

Anti-CLB monoclonal antibodies were produced using the hybridoma technique (Xu et al., 2005). The CLB antibody was diluted to a suitable working titer with DELFIA Assay Buffer and attached to the anti-rabbit IgG coated microtitration wells in a volume of $50 \mu \mathrm{l}$ per well. After a 1-h incubation, the wells were washed four times with DELFIA Wash Solution. The extracted samples $(25 \mu 1$ per well) and labelled analyte ( $25 \mu \mathrm{l}$ per well), which was diluted to an appropri-

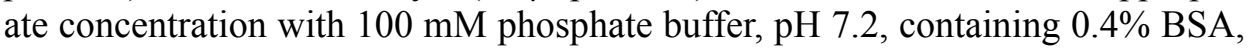
$0.05 \% \mathrm{NaN}_{3}$ and $20 \mu \mathrm{M}$ DTPA, were added to the wells and incubated for $30 \mathrm{~min}$. The wells were washed six times, after which $200 \mu \mathrm{l}$ of DELFIA Enhancement Solution was dispensed to each well. After a 15-min incubation period, the fluorescence signal was measured with a Victor 1420 Multilabel Counter using the default settings for europium measurement. 


\section{Determination by $G C-M S$}

The sample and standards were evaporated to dryness at $55^{\circ} \mathrm{C}$ under a mild stream of nitrogen and dissolved in $100 \mu \mathrm{l}$ toluene (votexed for about $10 \mathrm{~s}$ ). Then $100 \mu \mathrm{l} \mathrm{BSTFA}$ were added (votexed for about $10 \mathrm{~s}$ ), reacted at $80^{\circ} \mathrm{C}$ for $1 \mathrm{~h}$ to produce trimethylsilyl (TMS) derivatives of CLB. After cooling to room temperature, $300 \mu$ toluene were added (votexed for about $10 \mathrm{~s}$ ) for GC-MS analysis.

A Perkin-Elmer AUTOSYSTEMXLGC with autosampler system was coupled to a Perkin-Elmer TURBOMASS quadrupole mass spectrometer. Chromatographic separation was performed using a capillary column (HP-5MS; cross-linked 5\% phenyl-methylpolysiloxane; column length $(30 \mathrm{~m} \times 0.25 \mathrm{~mm}$ with a $0.25 \mu \mathrm{m}$ film thickness) from Agilent Technologies (Palo Alto, CA). The GC temperature program was as follows: initial temperature was $110^{\circ} \mathrm{C}$ for $1 \mathrm{~min}$, then the temperature was programmed to rise by $30^{\circ} \mathrm{C} \mathrm{min}^{-1}$ to $210^{\circ} \mathrm{C}$, and then increased at $5^{\circ} \mathrm{C}$ $\mathrm{min}^{-1}$ to a final temperature of $280^{\circ} \mathrm{C}$, which was held for $4 \mathrm{~min}$. The injector temperature was set at $250^{\circ} \mathrm{C}$. Helium was used as carrier gas at a flow rate of 1.3 $\mathrm{ml} \mathrm{min}{ }^{-1}$. The interface temperature was $280^{\circ} \mathrm{C}$, and the ion source temperature was $230^{\circ} \mathrm{C}$. Samples $(1 \mu \mathrm{l})$ were injected in the splitless mode.

The mass instrument was operated in the electronic impact ionization mode. Scan range: 50-550 amu; all data for quantification were collected in the selected ion monitoring (SIM) mode at $\mathrm{m} / z$ 86, 243, 262 and 277 for CLB.

\section{RESULTS AND DISCUSSION}

Cross-reactivity. The specificity of the MAb was evaluated using similar compounds structurally related to CLB and the results are presented in Table 1.

Table 1. Cross-reactivity(CR) of MAb to CLB and its analogs

\begin{tabular}{lc}
\hline Compound & $\mathrm{CR}, \%$ \\
\hline Clenbuterol & 100 \\
Cimaterol & 1.0 \\
Salbutamol & 0.8 \\
Terbutaline & 0.2 \\
Epinephrine & $<0.1$ \\
Norepinephrine & $<0.1$ \\
Fenoterol & $<0.1$ \\
Ambroxol & $<0.1$ \\
Phenylbutazone & $<0.1$ \\
Isoproterenol & $<0.1$ \\
Pirbuterol & $<0.1$ \\
Adrenaline & $<0.1$ \\
Fenoterol & $<0.1$ \\
\hline
\end{tabular}


The MAb exhibited high cross-reactivity (CR) with CLB. Therefore, it was concluded that the MAb was specific to CLB and could be used in immunoassays for CLB screening of animal tissues.

Reproducibility and accuracy. The standard curve for CLB prepared in the assay buffer is illustrated in Figure 1. Recovery experiments were conducted to evaluate the accuracy and precision of the TR-FIA. Recoveries were determined using blank pig liver samples fortified with 0.1 , 1 , and $5 \mathrm{ng} \mathrm{g}^{-1}$ CLB. Results of the recovery experiments are shown in Table 2 . The average recoveries from pig liver tissues were $89.3-117.9 \%$. The intra- and inter-assay coefficients of variation were less than 11.3 and $14.5 \%$.

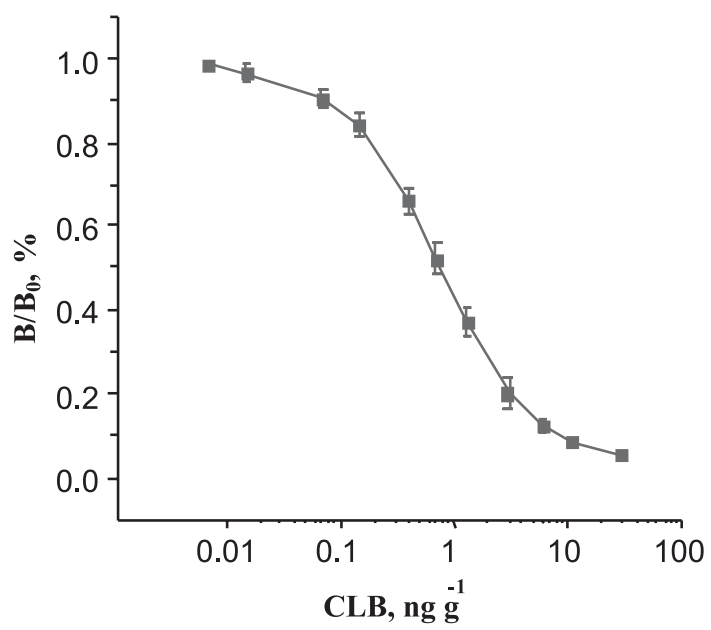

Figure 1. The standard curve for CLB by TR-FIA under optimized conditions

Table 2 Accuracy and precision of the TR-FIA CLB in spiked pig liver samples

\begin{tabular}{lcccc}
\hline \multirow{2}{*}{ Sample } & $\begin{array}{c}\text { Added } \\
\mathrm{ng} \mathrm{g}^{-1}\end{array}$ & $\begin{array}{c}\text { Recovery } \\
\%, \mathrm{n}=6\end{array}$ & $\begin{array}{c}\text { Intra-assay } \\
\mathrm{CV}, \%, \mathrm{n}=6\end{array}$ & $\begin{array}{c}\text { Inter-assay } \\
\mathrm{CV}, \%, \mathrm{n}=6\end{array}$ \\
\hline \multirow{3}{*}{ Pig liver } & 0.1 & 89.3 & 11.3 & 14.5 \\
& 1 & 117.9 & 10.3 & 13.1 \\
& 5 & 105.4 & 7.8 & 8.3 \\
\hline
\end{tabular}

$L O D$ and $L O Q$. The limit of detection (LOD), defined as mean $+3 \times \mathrm{SD}$ for CLB was determined by repeated analysis $(n=6)$ of CLB-free pig liver samples. The LOD was $0.02 \mathrm{ng} \mathrm{g}^{-1}$. The LOQ was $0.08 \mathrm{ng} \mathrm{g}^{-1}$ for pig liver tissues.

The performance of the new TR-FIA method was compared with that of ELISA kits using CLB-spiked samples $(n=25)$. CLB concentrations measured by the TRFIA and the ELISA were comparable. Linear regression analysis showed good correlation, with $r^{2}$ values of 0.97 for pig liver. 
Comparison with GC-MS. To further demonstrate reliability of the TR-FIA for the determination of CLB residues in animal tissues, 15 pig liver samples from local food markets were analysed using the TR-FIA and GC-MS methods. CLB was found in 5 out of 15 pig liver samples by both methods. CLB concentrations in these samples are presented in Table 3 and the trend line with $\mathrm{R}^{2}=0.89$ indicating that the TR-FIA and GC-MS results are more in agreement and show a higher degree of correlation.

Table 3. CLB concentrations in pig liver samples purchased from local food markets $(n=6)$

\begin{tabular}{lrc}
\hline \multirow{2}{*}{ Sample } & \multicolumn{3}{c}{ CLB, $\mathrm{ng} \mathrm{g}^{-1}$, mean \pm SD } \\
\cline { 2 - 3 } & TR-FIA & GC-MS \\
\hline 1 & $0.7 \pm 0.1$ & $0.5 \pm 0.2$ \\
2 & $4.6 \pm 0.3$ & $2.1 \pm 0.4$ \\
3 & $5.8 \pm 0.6$ & $4.3 \pm 0.3$ \\
4 & $1.9 \pm 0.3$ & $1.5 \pm 0.4$ \\
5 & $6.3 \pm 0.7$ & $4.9 \pm 0.6$ \\
\hline
\end{tabular}

\section{CONCLUSIONS}

In this study, a simple and rapid method for the analysis of low levels of CLB residues in pig liver tissues were established. The TR-FIA method offers significant improvement in sensitivity compared with conventional ELISA. Analysis of fortified and field samples demonstrated that the TR-FIA method is suitable for screening for CLB residues in animal tissues. This sensitive and stable immunoassay could be applied as a rapid screening method in routine drug residue analysis.

\section{REFERENCES}

Dykman L.A., Bogatyrev V.A., 1977. Colloidal gold in solid-phase assays. A review. Biochemistry (Moscow), 62, 350-356

Elliott C.T., Francis K.S., McCaughey W.J., 1994. Investigation of dissociation enhanced lanthanide fluoroimmunoassay as an alternative screening test for veterinary drug residues. Analyst 119, 2565-2569

Hooijernik H., Schilt R., Haasnoot W., Courtheijn D., 1991. Determination of clenbuterol in urine of calves by high-performance liquid chromatography with in series ultraviolet and electrochemical detection. J. Pharmaceut. Biomed. Anal. 9, 485-492

Mitchell G.A., Dunnavan G., 1998. Illegal use of beta-adrenergic agonists in the United States. J. Anim. Sci. 76, 208-211

Navarro-Martinez J.F., 1990. Food poisoning related to consumption of illicit $\beta$-agonist in liver. Lancet 336, 1311-1316

Polettini A., 1996. Bioanalysis of b2-agonists by hyphenated chromatographicand mass spectrometric techniques. J. Chromatogr. B 687, 27-42 
Ramos F., Cristino A., Carrola P., Eloy T., Silva J.M., Castilho M.C., da Silveira M.I.N., 2003. Clenbuterol food poisoning diagnosis by gas chromatography-mass spectrometric serum analysis. Anal. Chim. Acta 483, 207-213

Salleras L., Donguez A., Mata E., Taberrer J.L., Moro I., Salva P., 1995. Epidemiologic study of an outbreak of clenbuterol poisoning in Catalonia. Public Health Rep. 110, 338-342

Song Y.R., Wang D.F., Hu Y.P., Chen X.X., Jiao Y.G., Hou D.Y., 2003. Direct separation and quantitative determination of clenbuterol enantiomers by high performance liquid chromatography using an amide type chiral stationary phase. J. Pharmaceut. Biomed. Anal. 31, 311-319

Tuomola M., Cooper K.M., Lahdenpera S., Baxter G.A., Elliott C.T., Kennedy D.G., Lovgren T., 2002. A specificity-enhanced time-resolved fluoroimmunoassay for zeranol employing the dry reagent all-in-one-well principle. Analyst 127, 83-86

Van Hoof N., Courtheyn D., Antignac J.P., Van de Wiele M., Poelmans S., Noppe H., De Brabander H., 2005. Multi-residue liquid chromatography/tandem mass spectrometric analysis of betaagonists in urine using molecular imprinted polymers. Rapid Commun. Mass Spectrom. 19, 2801-2808

Xu C.L., Peng C.F., Hao K., Jin Z.G., Wang W.K., 2005. Determination of clenbuterol residual by chemiluminescent enzyme immunoassay. Chinese J. Anal. Chem. 33, 699-702 